Volume 7, No. 11 November 2019

International Journal of Emerging Trends in Engineering Research

Available Online at http://www.warse.org/IJETER/static/pdf/file/ijeter017112019.pdf

https://doi.org/10.30534/ijeter/2019/017112019

\title{
A Case Study on Rainwater Harvesting and Reuse in Jordan
}

\author{
Aymen Awad $^{1}$, Firas Al Bajari ${ }^{2}$ and Feras Al Adday ${ }^{3}$ \\ ${ }^{1}$ Middle East University, Amman, Jordan, aawad@ meu.edu.jo \\ ${ }^{2}$ Damascus University-Faculty of Architecture, Syria, f.bajari@gmail.com \\ ${ }^{3}$ Middle East University, Amman, Jordan, falkhalil@ meu.edu.jo
}

\section{ABSTRACT}

The problem of continuous decline in precipitation in the Arab countries and neighboring countries is one of the most important challenges facing countries and societies in this region. The increasing shortage of rainfall due to climate change in these regions in particular and in most countries in the world in general drives these countries and communities to over-extraction from groundwater, which could result in rapid loss, The concept of water harvesting is intended to try to make the most of rainfall by finding ways to ensure the accumulation of the largest possible rain precipitation and to store it for use in many areas and in some extent to reduce the groundwater ,The aim of this study is to develop some methods in urban treatments through the design of sidewalks and streets within the cities in order to allow the flow of rainwater and work to collect them in containers used later in the irrigation of gardens or in the requirements of fire extinguishing systems or any other urban needs. This case study was done in Al Madina Al Munawwarah Street in Amman, Jordan. The results said that the total amount of water can be collected during the rain seasons in the target area will be about $9146 \mathrm{~m}^{3} / \mathrm{y}$. This quantity can be used for a fire extinguisher or irrigation of plant or trees in the middle or at both sides of the street. This means that the water harvested over the Jordan area is about $243000000 \mathrm{~m}^{3}$.

Key words: Harvesting, Rainwater, Shortage, Commercial and Irrigation Uses and Jordan.

\section{INTRODUCTION}

From time immemorial, man has realized the importance of water as one of the most vital needs for him and his daily activities and as one of the most important elements in his philosophy of survival and prosperity. The problem of water scarcity is one of the biggest challenges facing our world today due to several factors, the most important of which are global warming, climate change and the excessive use of underground water.
According to Omar Al-Khateeb in 2007 [5], some factors contribute to the water shortage in the Middle East region and the world. For example, the high population growth, high water demand, rare of water in the desert areas, deterioration of the water networks for water distribution across the region and high cost of water transport and treatment.

Jordan is located in an arid zone to semi-arid; harsh weather conditions. The variability in related hydrological parameters such as precipitation, runoff, and large evaporation and they vary from day to day, from summer to winter, and year to year[4].

On the regional level, our region in general and the Hashemite Kingdom of Jordan in particular, as well as many Arab countries, Water resources from rivers, lakes or springs where these areas rely heavily on rainwater to meet the living needs of water for agriculture, drinking or for daily use and more importantly groundwater recharge, which has recently been increased to over-pumping of water unjust that much about recharging ratios for these resources increases by the decrease in the amount of annual rainfall, which could lead in the near future to the depletion of these resources. The annual precipitation amounts in the Arab countries range from 100 $\mathrm{mm}$ per year to $300 \mathrm{~mm}$ per year at a maximum. This is considered to be one of the lowest rates in the world of precipitation quantities, however, more than $90 \%$ of the precipitation is lost by evaporation and about $8 \%$ of the precipitation is lost by surface runoff and only $2 \%$ of this precipitation is known as groundwater recharge [4]. In general, Jordan couldn't harvest more than $15 \%$ of the average annual rainfall in most years. This is serious problem in water sector in the country. This mean that the water concerning authorities must implement an emergency plan to rehabilitate and improve the resources of water in the country which has to be developed by the government authorities to avoid the water lacks for different usages.

Jordan is one of the poorest countries in water in the world and region. Jordan area is about $89,000 \mathrm{~km}^{2}$ located in an arid and semi-arid region. It was estimated that the annual precipitation in most of the kingdom areas ranged from 50 to $600 \mathrm{~mm}$ [3]. It is true that most of water losses in Jordan is due to evaporation which reaches about $91 \%$ and $4 \%$ due to 
aquifers recharges. Therefore Jordan water resources are completely dependent on rainfall [4], as shown in figure 1 . The portion of water for each capita in Jordan is of the lowest all over the world. Since the country has a high growth rate of the population then the shortage of water will be a clear feature in water issues and challenges in the next two decades. To overcome this problem government authorities have to do high efficient management plans for the rehabilitation of water resources.

This will solve the problem of the increased in water demand in the country. Increasing overall water extraction to fulfill demand carries a high value. Groundwater the most supply in Jordan thanks to the limitation of surface water resources. The groundwater resources have been exploited since the 1950s by government and private sectors with few wells to reach more than 4000 wells nowadays [2].

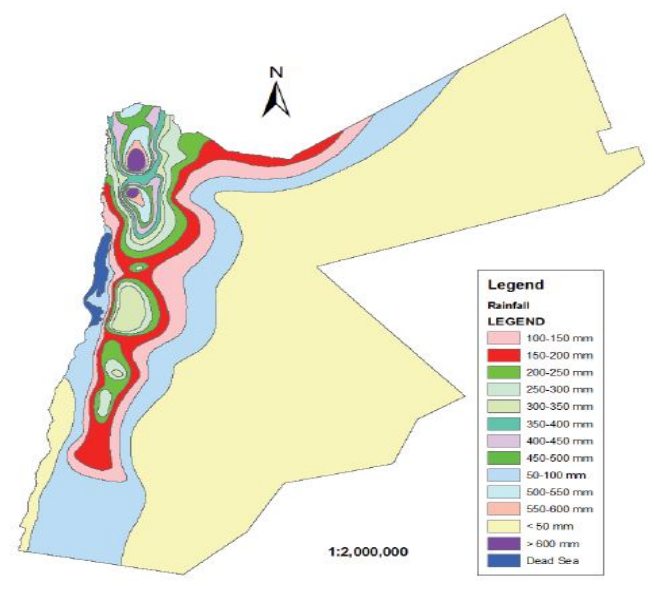

Figure 1: Spatial rainfall variability in Jordan.

Jordan is characterized by severe weather conditions, therefore great temporal and spatial variations in rainfall; runoff and evaporation amounts are expected [10]. Water harvesting has been practiced in Jordan throughout history for both irrigation and household purposes [6], [8]. Water harvesting to collect and use water is gaining a lot of interest in Jordan. The Ministry of Water and Irrigation has put a study for water harvesting that includes the building of many earth dams and water ponds, Haffir, in about 80 locations all over the country [1]. It is a fact that the average rainfall in Jordan is about $279 \mathrm{~mm} /$ year. Water harvesting is one of the most effective methods to collect or generate water. The amount of water which may be collected from a roof area of $125 \mathrm{~m}^{2}$ in the rainy season is about $35 \mathrm{~m}^{3}$ [7].

\section{RESEARCH PROBLEM}

The research problem is reflected in the increasing problem of water scarcity in the Kingdom of Jordan due to the decrease in the amounts of rainfall and the use of temperature according to the phenomenon of global warming and the increase of the population steadily leading to an increase in demand for the use of groundwater but without recharging to the groundwater aquifers to equalizing the corresponding proportion of this large loss of groundwater, which makes it imperative for us as researchers to try to think in the development of plans and studies of ways to benefit from rainfalls of rain to the maximum in an attempt to stop losing of water to the underground water resources or by evaporation by used sustainable ways of collection and supporting this wealth and achieving a part of the water security in the Kingdom.

\section{RESEARCH GOALS}

The purpose of this research is to provide a first assessment of the current status of water harvesting in Jordan, using an illustrative example from the capital Amman region by selecting an urban area as a case study. The details of the urban areas will be studied. Purification and storage for later use in the service of this area during periods of rainfall and thus reduce the dependence on the groundwater from some extent in terms of securing alternative water resources during the dry seasons.

\section{METHODOLOGY AND WATER HARVESTING MANAGEMENT}

The concept of rainwater management. In principle, three levels of rainwater harvesting management can be identified in a set of procedures, techniques, observations and statistics: Level 1. Pre-precipitation requirements. There are a number of procedures to be carried out in the pre-rainy seasons in the region in order to develop and implement appropriate plans and regulations for the management of water harvesting from the preparation of studies and accurate statistics for a number of factors that play an important role in the water harvesting process.

- Conducting accurate and continuous statistics for at least several years prior to establishing the accurate average annual precipitation rates for the study area, including the distribution of this precipitation over the months and expected flows - the quantities of water expected to be collected.

- Statistics on the quantities of water expected to be consumed by the residents or workers in the study area or the required quantities of water for the work of civil defense and fire extinguishing.

- Estimating the quantities required to be collected in order to secure the required volumes for storage areas (reservoirs).

- Ensure the safety and effectiveness of these systems and work to maintain them in the period before the descent of rain in order to help them to perform its work efficiently during the rainy periods. 
Level II. Requirements during rainy periods. There are requirements during rainfall periods to monitor and manage water collection systems and ensure that they are functioning efficiently to ensure the flexibility of water harvesting management to avoid any risks that may occur as a result of any emergency shortfalls. The impact of traffic flow on the streets) or because of an unexpected increase in rainfall and in larger quantities than the collection tanks.

Level III. Post-rain requirements. There are post-rain requirements to determine the results of the work of the systems and their degree of efficiency and estimate the quantities of savings of water collected, which contribute indirectly to the conservation of groundwater, in addition to the development of further plans to expand the areas and quantities of water collection in order to achieve an integrated water harvesting system for the whole city As well as to identify the future maintenance requirements and identify the points of challenges and defects in the future.

Even in some areas where the water is supplied by networks, harvested rainwater is a significant supplemental resource for domestic especially during the summer season when low quantity after is supplied. Currently, in Jordan, rooftop water harvesting is being practiced for drinking water, stick uses, and livestock and for garden irrigation [9].

Suggested Case Study (Amman) Madina Al Munawwarah Street. It is obvious that the Hashemite Kingdom of Jordan is considered one of the countries that suffer from water shortage in water resources, such as rivers, springs, etc., as well as the decline and decline in annual precipitation rates, as well as other countries in the world and the region. Jordan is heavily affected by climate change by its location, nature and nature, which is the closest to the desert climate in much of the Kingdom's land, as a result of the large and increasing population growth and the increase in refugee populations in recent years. As a result, these factors have contributed significantly to increasing the pressure on governments in the areas of finding water resources to meet the needs of the communities, which resulted in the exploitation of groundwater and groundwater in various regions of the Kingdom.

Rainfall precipitation rates in the Hashemite Kingdom of Jordan range from 100-300 mm annually. These rates have recently been reduced. This requires researchers and those interested in the environmental and urban areas to try to find modern and innovative methods to reduce the loss of groundwater through the application of water harvesting methods within cities. This research will attempt to propose solutions to the area located on the axis of Madina $\mathrm{Al}$ Munawwarah Street between Al-Waha Circle and the University of Jordan Complex on a main street in Amman and on a selected area of $941 \mathrm{~m}$ and $54 \mathrm{~m}$ as shown in Figure 2.

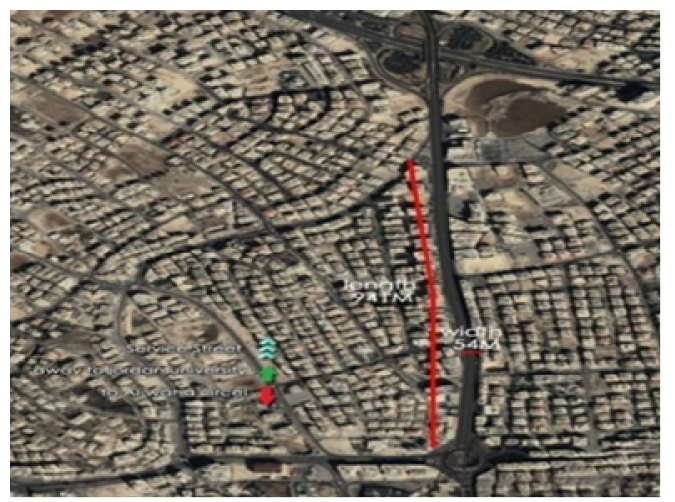

Figure 2: The study area extends between the Oasis roundabout to the south and the Sultan's markets to the north.

This street is characterized by commercial character in general and is characterized by a great intensity of the returnees, which makes the study of the experience of water harvesting is of great importance in an attempt to secure part of the needs of shops and businesses on both sides of the street or in terms of securing key points of civil defense system nozzles and extinguishing the fire on partial ends of the street. The total width of the street is about $54 \mathrm{~m}$. It is composed of two directions, each with four lanes, each of which is about 12 $\mathrm{m}$. Each direction is characterized by a service road for three cars, width of about $9 \mathrm{~m}$ on each side and a middle island in the street width of $2 \mathrm{~m}$, in addition to two sidewalks between the street and the service road each is $2 \mathrm{~m}$ as shown in Figure 3.

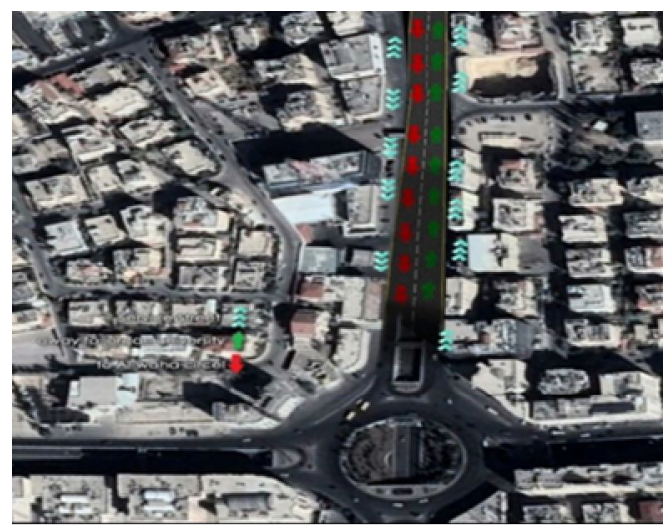

Figure 3: The street view area shows both directions and routes on both sides of the street.

\section{PROPOSED URBAN SOLUTIONS TO ENHANCE WATER HARVESTING EXPERIENCE}

These solutions are to benefit from the areas of sidewalks and footpaths as rainwater harvesting areas after being properly designed to allow them to be used in the collection and purification of rainwater and then linked to the pipelines which connect this water to the reservoirs created under the street to allow storage and utilization of precipitation for use in dry seasons (as illustrated in Figure 4). The proposed design provides the inclination for asphalt roads to collect rainwater towards the sidewalks. The openings required to 
enter this water are secured to the dirt areas of the plant basins and then to the gravel layer, which works to purify the water from the impurities and reach the collection pipe. Thus, the flow of water is managed from the street and directed towards the places of the ponds.

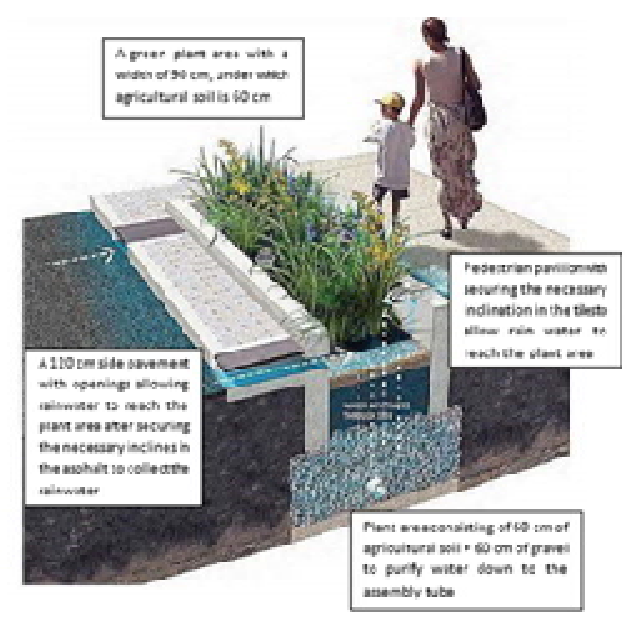

Figure 4: Demonstrates the proposed method of harvesting rainwater- 2018 Philadelphia Water Department.

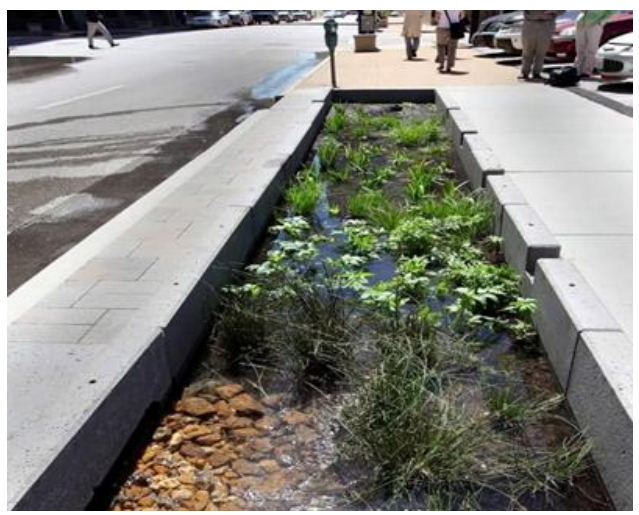

Figure 5-A

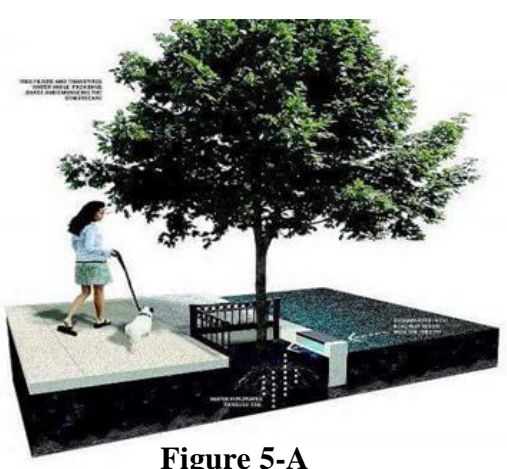

Figure 5-A: Illustrates the proposed method of collecting rain water through the openings in the sides of the plant basins after securing the necessary inclination in the pavement tiles. Figure 5-B: Method of Design and Implementation of Tree Basins for Storm water Harvesting - 2018 Philadelphia Water Department.
It is also possible to use the tree planting basins on both sides of the street for water harvesting after providing the necessary openings to draw rainwater from the asphalt road towards the tree basins, taking into account the layer of gravel also under the agricultural soil and deep thickness to clear the water collected from impurities (Figures 5 - A \& B).

The modern types of materials used for paving the sidewalks, such as the enter look, can be used for concrete slabs of this type, which are anchored on a floor of a layer of sand beneath which a concrete layer allows the rainwater to flow into the concrete layer, Towards the collecting areas, the plant basins and the gravel layer (Figure 6).

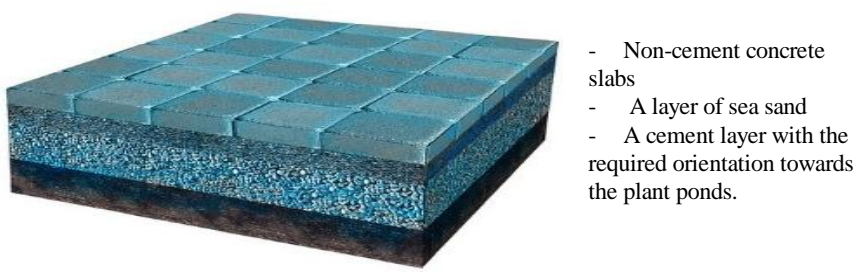

Figure 6: A proposal for the implementation of the sidewalks of the sidewalks illustrates a system that allows water flow management - 2018 - Philadelphia Water Department.

5.1 Runoff and water harvesting at studied area. According to the historical data for the rain fall amount it is concluded that the rainfall intensity at the suggested catchment is arranged from 100 to $300 \mathrm{~mm} /$ year, the area is $941 \mathrm{~m} \mathrm{X} 54 \mathrm{~m}$, it means $50814 \mathrm{~m}^{2}$ or $0.0508 \mathrm{~km}^{2}$. The runoff coefficient ( $\mathrm{RC}$ ) for paved area (Catchment Area) is estimated to be $(0.6-0.80)$ and adapted a 0.70 for this studied. The quantity of water that runs off a paved area in the street into gutter system is usually calculated using the rational method by the following equation [8]:

$Q=\mathrm{C} \times \mathrm{I} \times \mathrm{A}$

(1)

Where $Q$ is the quantity of water that runs off, $\mathrm{C}$ is the runoff coefficient, $I$ is the rain intensity of the rainfall in $(\mathrm{mm} / \mathrm{y})$, and $A$ is the paved area or the catchment area $\left(\mathrm{m}^{2}\right)$. Since $\mathrm{C}$ is 0.90 (as adopted for this study), the intensity (I) is on average about $200 \mathrm{~mm} / \mathrm{y}$ (for Madina Al Munawwarah Street region), and $A$ is $50814 \mathrm{~m} 2$, then the quantity of water that represents runs off $(\mathrm{R})$ or $(Q)$ is $9146 \mathrm{~m}^{3} / \mathrm{y}(\approx 9146000 \mathrm{~L} / \mathrm{y})$ or $(25057 \mathrm{~L} /$ day $)$. The amount of water evaporated is about $90 \%$ of the total rainfall [2]. So the water that can be harvested is 2505.7 $\mathrm{L} /$ day. However, if the runoff coefficient on average values for area of the Kingdom ( $\mathrm{C}$ ) is 0.80 and the area of Jordan is estimated to be $90000 \mathrm{~km}^{2}$ and the average intensity (I) is about $270 \mathrm{~mm} /$ year and the average rate of evaporation $90 \%$, then the amount of water which can be harvested during rainy season in Jordan is estimated to be $\left(0.1 * 0.8 * 90000 \mathrm{~km}^{2}\right) *$ $\left(10^{6} \mathrm{~m}^{2} / \mathrm{km}^{2}\right) *(270 \mathrm{~mm} / \text { year })^{*}(1 \mathrm{~m} / 1000 \mathrm{~mm})=243 \times 10^{6}$ $\mathrm{m}^{3} /$ year. This amount is the volume needed for storage of harvested water which can be used for irrigation, fire extinguishing, and other purposes. This means that the water 
Aymen Awad et al., International Journal of Emerging Trends in Engineering Research, 7(11), November 2019, 398 - 402

harvested structures in Jordan can be full by developing the water harvesting methods in time and locations. Since the capacity of the existing water harvesting structures (Dams, Pools and Ponds) is about $243,000,000 \mathrm{~m}^{3}$ which represents about $13 \%$ of the total water demands in Jordan, the water harvesting strategy is success and benefit to reduce water shortages in Jordan.

\section{CONCLUSION}

Jordan is considered one of the countries that suffer from water shortage in water resources, such as rivers, springs, etc. It is concluded that rainwater could be collected by different ways. Water harvesting in developed areas one of the most effective methods to contribute in lowering the water shortage in Jordan. Rain water could be utilized for different beneficial uses. Fire demand in water supply system is one of these usages. Over the studied area the results said that the total amount of water can be collected during the rain seasons (4 months) will be about $9146 \mathrm{~m}^{3} / \mathrm{y}$. This quantity can be used for a fire extinguisher or irrigation of plant or trees in the middle or at both sides of the target area.

\section{ACKNOWLEDGMENT}

The author is grateful to the Middle East University, Amman, Jordan for the financial support granted to cover the publication fee of this research article.

\section{REFERENCES}

1. Abu-Zreig, M. Water management scenarios under scarcity conditions in Jordan. IX World Water Congress. Montrial, Canada, 1-6, September 1997.

2. Bassam Mohammed Al-Qaisi. Climate Change effects on Water Resources in Amman Zarqa Basin Jordan. Ministry of Water and Irrigation, Climate Change mitigation and adaptation, Norrkoping Sweden, October 25 - November 19, 2010.

3. D. Prinz. Water Harvesting: Past and Future, In: $L . S$. Pereira, Ed., Proceedings of Sustainability of Irrigated Agriculture, NATO Advanced Research Workshop, Vimeiro, Balkema, Rotterdam, 21-26 March 1996, pp. 135-144.

4. Khoury, Jean. Droubi, AbdUllah. National Plan for Arab Water Security. Agriculture and water. Number: 11. July. P. 4-16. ACSAD. Damascus.

5. Omar Al-Khateeb. Evaluation of Water Harvesting Techniques under Semi-Arid Environment North of Jordan. Jordan University of Science \& Technology, Natural Resources \& Environment-Soil Water \& Environment, 2007.

6. R. A. AbdelKhaleq and I. Ahmed Alhaj. Rainwater Harvesting in Ancient Civilizations in Jordan, Water Science \& Technology: Water Supply, Vol. 7, No. 1, 2007, pp. 85- 93. doi:10.2166/ws.2007.010.
7. Salameh. E. and Bannayan. H. Water Resources of Jordan: Present Status and Future Potentials, Friedrich Ebert Stiftung, Amman-Jordan. pp 4-7.

8. T. H. Thomas and D. B. Martinson. Roof water Harvesting, A Handbook for Practitioners, IRC International Water and Sanitation Centre, Delft, The Netherlands, 2007.

9. Water Sensitive Urban Design Technical Manual. Greater Adelaide Region - Urban Water Harvesting and Reuse. Government of South Australia - Department of Planning and Local Government- Roma Mitchell House, 136 North Terrace, Adelaide SA 5000- GPO Box 1815, Adelaide SA 5001.

10. Z. S. Tarawneh, N. A. Hadadin and A. N. Bdour, Policies to Enhance Water Sector in Jordan, American Journal of Applied Sciences, Vol. 5, No. 6, 2008, pp. 698- 704. doi:10.3844/ajassp.2008.698.704, [Citation Time(s):1]. 